\title{
Best Practices in Nutritional Supplementation and Ergogenic Aids
}

\author{
Timothy M Dornemann* \\ School of Allied Health and Sports Studies, USA
}

Submission: May 24, 2017; Published: August 23, 2017

*Corresponding author: Timothy M Dornemann, Ed.D, School of Allied Health and Sports Studies, Barton College Wilson, North Carolina, Email:

\section{Introduction}

Nutrition is an essential element of our human existence, what we eat impacts how our body functions. Our body requires nutrients to be able to function properly and provide energy. In athletics our nutritional needs are heightened as physical activity places increased demands on the body. The field of sports nutrition has evolved to help determine how to maximize athletic performance and development. Proper sports nutrition helps to enhance body processes, aid in the maintenance and development of tissue, and provide the fuel needed to meet the energy demand of activity.

Being knowledgeable about sports nutrition can provide athletes with a competitive edge. Athletes need to know what to eat to provide energy for the activities they participate in. The proper timing of nutrient consumption can enhance storage of nutrients and recovery. The study of sports nutrition helps determine the increased nutritional needs of athletes and what nutritional supplements are safe and effective. The following is a listing of best practices in sports nutrition taken from the exercise and sport nutrition review produced by the International Society of Sports Nutrition (ISSN) [1].

a. ISSN recommend s that an athlete's diet should consist of $55-65 \%$ carbohydrates or $5-8$ grams $/ \mathrm{kg} / \mathrm{day}$.

b. Athletes that routinely perform high volumes of intense training (3-6 hours of intense exercise 1-2 workouts for 5-6 days per week) may need up to $8-10 \mathrm{grams} / \mathrm{kg} /$ day.

c. Ingesting carbohydrates with protein at a 3-4 to 1 ratio during and after activity has been found to be beneficial in replacing energy and enhancing recovery.

d. Due to heightened energy requirements and increased need to build and maintain tissue, both endurance and strength athletes require a greater amount of protein in their diets. ISSN recommends that athletes take in 1.4-2.0grams/kg/day of protein.

e. To help prevent dehydration, athletes should drink 6-8 fluid ounces of water or sports drink every 5 to 15-minutes.

f. ISSN recommends that athletes should weigh in before and after activity and drink 2-3 cups of water for every pound loss in order to maintain proper hydration.

g. The antioxidant effects of Vitamins A, C, and E may help athletes tolerate exercise better and enhance recovery.

h. Electrolytes (sodium, potassium, and calcium) are often included with carbohydrates in sports drinks to help prevent dehydration and enhance prolonged endurance exercise capacity.

i. Increased sodium intake is recommended during the first couple days of training in heat and humidity to help maintain fluid balance and prevent dehydration.

j. Of the substances that ISSN categorizes as "apparently effective" creatine monohydrate is described as the most effective ergogenic nutritional supplement.

k. Other "apparently effective" substances are sodium phosphate, sodium bicarbonate, and caffeine.

Nutrition does not always receive the attention it deserves, proper nutrition is vital to maximizing athletic training and performance. Poor nutrition and insufficient calorie intake can hamper performance and render the most advanced training programs ineffective. Serious athletes take nutrition seriously if they want to maximize their athletic abilities. Sports nutrition is an ever evolving science that must be studied to be utilized properly. Coaches and athletes need to be able to 
sift through the vast quantity of information available and discern from quality research how to eat properly and how to use supplements effectively.

This work is licensed under Creative Commons Attribution 4.0 License DOI: $10.19080 /$ NFSIJ.2017.03.555603

\section{References}

1. Kreider RB, Wilborn CD, Taylor L, Campbell B, Almada AL, et al. (2010) ISSN exercise and sport nutrition review: research and recommendations. J Int Soc Sports Nutr 7: 7

\section{Your next submission with Juniper Publishers will reach you the below assets}

- Quality Editorial service

- Swift Peer Review

- Reprints availability

- E-prints Service

- Manuscript Podcast for convenient understanding

- Global attainment for your research

- Manuscript accessibility in different formats

( Pdf, E-pub, Full Text, Audio)

- Unceasing customer service

Track the below URL for one-step submission https://juniperpublishers.com/online-submission.php 